\title{
The influence of amount of copper of modified vermiculites on catalytic properties in SCR-NH
}

\author{
Bogdan Samojeden ${ }^{1, *}$, Marek Możdżeń ${ }^{1}$ \\ ${ }^{1}$ Department of Fuels Technology, al. A. Mickiewicza 30, 30-059 Kraków, AGH University \\ of Science and Technology
}

\begin{abstract}
Vermiculite was prepared by modifications with nitric acid, pillaring with $\mathrm{Al}$ oligocations and polymer (polyamide), impregnation with $\mathrm{Cu}$. Obtained products were used as catalysts in SCR-NH 3 process. All modifications increased catalytic performance compared to base vermiculite which was used as a reference. Sample pillared with polymer and impregnated with $5 \%$ wt. $\mathrm{Cu}$ showed best catalytic properties in the process, compared to other polymer and $\mathrm{Cu}$ modified samples.
\end{abstract}

\section{Introduction}

Nitrogen oxides, referred as $\mathrm{NO}_{\mathrm{x}}$, are one of the main pollutants deriving from fuels combustion. They are connected with admixtures and impurities in fuels or may occur as a product of side reactions. The negative impact of $\mathrm{NO}_{\mathrm{x}}$ on the environment cannot be neglected since they are the cause of acid rains and degeneration of ozone layer. The main product of fuel combustion is nitrogen monoxide (NO), which undergoes oxidation to $\mathrm{NO}_{2}$ in contact with oxygen from the atmosphere. Subsequently, nitrogen dioxide reacts with water, hence the nitric acid is created, which is one of the components of acid rains. Moreover, $\mathrm{NO}_{\mathrm{x}}$ in general take part in the formation of smog and also are one of the greenhouse gases [1].

Hence the need to reduce emission of such pollutants, and that is where SCR comes to the aid. There are two ways of such reduction [2]: modification of combustion process and conversion of flue gases. Nowadays SCR is the most effective and most widely used method of $\mathrm{NO}_{\mathrm{x}}$ removal from flue gases emitted by stationary sources. It is a process where $\mathrm{NO}_{\mathrm{x}}$ are reduced to molecular nitrogen and water, with the aid of various catalysts. $\mathrm{NO}_{\mathrm{x}}$ reduction takes place when the gases pass through the catalyst chamber in the installation, while reductants, such as ammonia or urea, are mixed with the gases (injected into the stream) prior. Main reactions occurring in SCR are as follows [3]:

$$
\begin{gathered}
4 \mathrm{NO}+4 \mathrm{NH}_{3}+\mathrm{O}_{2}=>4 \mathrm{~N}_{2}+6 \mathrm{H}_{2} \mathrm{O} \\
4 \mathrm{NH}_{3}+3 \mathrm{O}_{2}=>2 \mathrm{~N}_{2}+6 \mathrm{H}_{2} \mathrm{O} \\
2 \mathrm{NO}_{2}+4 \mathrm{NH}_{3}+\mathrm{O}_{2}=>3 \mathrm{~N}_{2}+6 \mathrm{H}_{2} \mathrm{O}
\end{gathered}
$$

SCR process utilizes reducing agents such as anhydrous ammonia, aqueous ammonia and urea. Thanks to the use of catalyst, NO reduction process can be maintained at lower temperatures $\left(300-400^{\circ} \mathrm{C}\right.$ compared to $\sim 1000^{\circ} \mathrm{C}$ as in non-catalytic process).

\footnotetext{
*Corresponding author: bsamo1@agh.edu.pl
} 
Typical industrial catalysts for this process are vanadium (V) oxide promoted with tungsten (IV) oxide on the carrier made of titanium (IV) oxide set on the monolith. The highest activity for such catalyst is at temperatures ranging from 250 to $400^{\circ} \mathrm{C}$. In energetic installations, it is most commonly placed after the boiler and before the precipitator. However, such placement exposes the catalyst to harmful effects of various dusts and sulfide (IV) oxide, which reduces its lifetime [3]. Hence the need to study new catalysts with suitable properties for SCR process. So far, activated carbons and clay minerals are thoroughly studied to meet the conditions of a good SCR catalyst. Vermiculite and montmorillonite seem to be most suitable candidates thanks to their properties and ease of modification. It is also proved, that the addition of transition metals, such as $\mathrm{Fe}$ and $\mathrm{Cu}$ have great impact on catalytic properties [4]. Clay minerals, as layer materials can undergone numerous modifications, where the most important one, apart from acid activation, is pillaring with various agents, such as oligocations (Keggin ions) or polymers. Introduction of oligocations is a well known process, that leads to increase of the distance between layers. Because of such improvement, additional agents can be placed inside the material, hence giving or improving catalytic properties [5]. Since carbon (in form of activated carbon), gives very good catalytic results in SCR process [6], a polymer (polyamide) was used to introduce it into the vermiculite. The purpose of such modification was to check the impact of carbon, in other form than activated carbon which is already used as catalyst, on catalytic properties in the process.

\section{Experimental and results}

\subsection{Sample preparation}

Base material, natural vermiculite supplied by Sigma-Aldrich Company, has undergone various modifications, which purpose was to give/improve catalytic properties. All modification steps are shown in Figure 1.

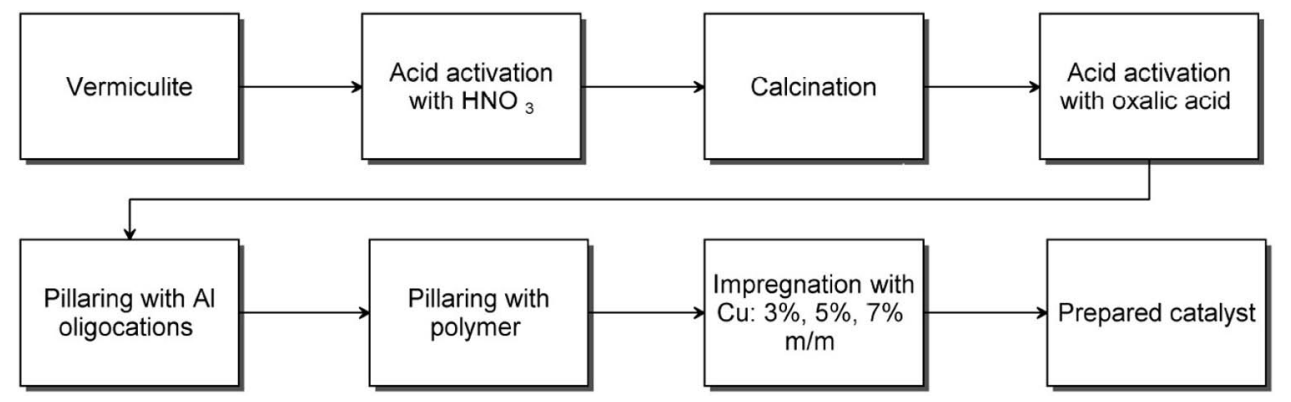

Fig.1 Preparation of samples

The first step of modification was the acid activation with $20 \%$ solution of nitric acid. Process was carried out at the acid boiling point under constant stirring for one hour. Activated material was filtrated, washed with distilled water to neutral $\mathrm{pH}$. Then, vermiculite was calcined at $600^{\circ} \mathrm{C}$ for 4 hours. The next step was acid activation with $0.12 \mathrm{M}$ solution of oxalic acid, at $80^{\circ} \mathrm{C}$ under constant stirring for 3 hours (then filtrated, washed with distilled water and dried for 24 hours at $80^{\circ} \mathrm{C}$ ) followed by pillaring with $\mathrm{Al}$ oligocations. Pillaring agent was prepared by slow addition of $0.4 \mathrm{M} \mathrm{NaOH}$ to $0.4 \mathrm{M}$ solution of $\mathrm{AlCl}_{3}$, under constant stirring for 24 hours. $\mathrm{OH} / \mathrm{Al}$ ration was equal 2.4. After that, the pillaring solution was left to age in room temperature for 72 hours. Pillaring process was carried out under the following conditions: pillaring solution was slowly added to the activated vermiculite suspension of $2 \% \mathrm{wt}$. in distilled water, in an amount of $12 \mathrm{mmol}$ of $\mathrm{Al}$ per $1 \mathrm{~g}$ of vermiculite, for about 24 
hours. Pillared vermiculite was subsequently washed with distilled water until disappearance of chloride ions and dried for 24 hours at $80^{\circ} \mathrm{C}$. Furthermore, Al-modified vermiculite was additionally pillared with polymer (polyamide). $5 \%$ wt. solution was added into Al-pillared vermiculite and stirred constantly for 24 hours at room temperature. Then it was filtrated and dried for 24 hours at ${ }^{\circ} \mathrm{C}$. The final step was the incipient wetness impregnation. The $\mathrm{Cu}$ ions precursor, $\mathrm{Cu}\left(\mathrm{NO}_{2}\right)_{2}$, was added as a 3, 5 and $7 \%$ wt. solution in respect to vermiculite mass. Material was dried for 24 hours at $80^{\circ} \mathrm{C}$, hence the prepared catalyst was obtained.
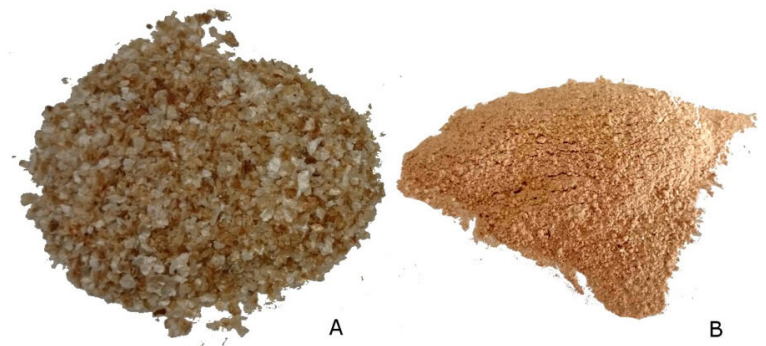

Fig.2 Modified vermiculite before (A) and after (B) pillaring

\subsection{Catalytic tests}

Prepared samples were tested as catalysts in the selective catalytic reduction of $\mathrm{NO}_{\mathrm{x}}$ with ammonia. All tests were performed on AGH University of Science and Technology, Kraków, Poland. Parameters of SCR process were as follows:

- the reaction gas - $800 \mathrm{ppm} \mathrm{NO}, 800 \mathrm{ppm} \mathrm{NH}_{3}$, in He with $3 \% \mathrm{v} / \mathrm{v}$ addition of $\mathrm{O}_{2}$;

- gas velocity - $100 \mathrm{ml} / \mathrm{min}$;

- reaction temperature $-150-400^{\circ} \mathrm{C}$;

- mass of the catalyst - 200mg;

- gas flow controller - ABB Uras-14;

- Concentration of gases in product stream measured every 65 seconds by NDIR (nondispersive infrared sensor) (Hartmann and Braun).

NO conversion was calculated based on formula:

$$
\text { NO Conversion [\%] }=\frac{\mathrm{NO}_{\text {in }}-\mathrm{NO}_{\text {out }}}{\mathrm{NO}_{\text {in }}} * 100 \%
$$

Table 1 explains the preparation of samples and assigned symbols.

Table 1. Parameters of prepared samples

\begin{tabular}{lcccccc}
\hline Sample & $\mathrm{V}$ & $\mathrm{VN} 20$ & $\mathrm{VN} 20 \mathrm{~g}$ & $\mathrm{VN20g} 3$ & $\mathrm{VN} 20 \mathrm{~g} 5$ & $\mathrm{VN20g} 7$ \\
\hline $\begin{array}{l}\text { Acid } \\
\text { activation }\end{array}$ & - & $\begin{array}{c}\mathrm{HNO}_{3} \\
20 \%\end{array}$ & $\begin{array}{c}\mathrm{HNO}_{3} \\
20 \%\end{array}$ & $\begin{array}{c}\mathrm{HNO}_{3} \\
20 \%\end{array}$ & $\begin{array}{c}\mathrm{HNO}_{3} \\
20 \%\end{array}$ & $\begin{array}{c}\mathrm{HNO}_{3} \\
20 \%\end{array}$ \\
\hline $\begin{array}{l}\mathrm{Cu} \\
\text { impregnation }\end{array}$ & - & - & - & $3 \%$ & $5 \%$ & $7 \%$ \\
\hline Al-pillaring & - & + & + & + & + & + \\
\hline $\begin{array}{l}\text { Polymer } \\
\text { pillaring }\end{array}$ & - & - & + & + & + & + \\
\hline
\end{tabular}


Table 2 shows the results of catalytic tests performed at $150,200,250,300,350$ and $400{ }^{\circ} \mathrm{C}$ in the form of $\mathrm{N}_{2} \mathrm{O}$ concentrations at the outlet and $\mathrm{NO}$ conversions.

Table 2. $\mathrm{N}_{2} \mathrm{O}$ concentration and $\mathrm{NO}$ conversion at given temperatures

\begin{tabular}{|c|c|c|c|c|c|c|c|}
\hline \multirow{2}{*}{ Parameter } & \multirow{2}{*}{$\begin{array}{c}\text { Temperature } \\
{\left[{ }^{\circ} \mathrm{C}\right]}\end{array}$} & \multicolumn{6}{|c|}{ Sample } \\
\hline & & V & VN20 & VN20g & VN20g3 & VN20g5 & VN20g7 \\
\hline \multirow{6}{*}{$\begin{array}{c}\mathrm{N}_{2} \mathrm{O} \\
\text { Concentration } \\
{[\mathrm{ppm}]}\end{array}$} & 150 & 12 & 38 & 155 & 187 & 323 & 214 \\
\hline & 200 & 14 & 48 & 165 & 191 & 340 & 232 \\
\hline & 250 & 15 & 68 & 172 & 200 & 352 & 255 \\
\hline & 300 & 27 & 103 & 175 & 206 & 356 & 265 \\
\hline & 350 & 17 & 112 & 176 & 234 & 393 & 297 \\
\hline & 400 & 29 & 177 & 188 & 213 & 362 & 260 \\
\hline \multirow{6}{*}{$\begin{array}{c}\text { NO } \\
\text { Conversion } \\
{[\%]}\end{array}$} & 150 & 0.5 & 0.5 & 7.1 & 8.2 & 1.6 & 2.0 \\
\hline & 200 & 3.0 & 15.2 & 16.1 & 10.0 & 19.6 & 15.7 \\
\hline & 250 & 6.9 & 55.6 & 61.4 & 32.4 & 51.0 & 51.1 \\
\hline & 300 & 8.9 & 90.1 & 93.1 & 66.2 & 80.0 & 82.6 \\
\hline & 350 & 9.3 & 98.2 & 92.7 & 93.4 & 94.3 & 92.6 \\
\hline & 400 & 12.4 & 60.5 & 61.5 & 64.4 & 60.3 & 61.2 \\
\hline
\end{tabular}

\subsection{Discussion}

As can be seen in general in Figures 5 - 11, which were prepared based on Table 2, the biggest difference in $\mathrm{N}_{2} \mathrm{O}$ concentration at the outlet, as well as $\mathrm{NO}$ conversion, occurs between nonmodified (or only activated) vermiculites and modified ones. It is connected with enhancing catalytic properties via acid activation and pillaring. Base vermiculite (V), shows minimal, practically insignificant ability to catalyze SCR process (maximum NO conversion $12.4 \%$ ), thus this sample is considered only as a reference. As a general rule for all modified vermiculites, with temperature increase, $\mathrm{NO}$ conversion rises, up to $350{ }^{\circ} \mathrm{C}$, then slightly goes down at $400{ }^{\circ} \mathrm{C}$. It means, that $350{ }^{\circ} \mathrm{C}$ is an optimal temperature for those catalysts.

Catalytic performance for polymer-modified samples with addition of $\mathrm{Cu}$, varies between temperatures. Generally lower performance (compared to sample VN20) at $250-350{ }^{\circ} \mathrm{C}$ range, may be caused as a result of covering the active phase by polymer chains [7]. In case of montmorillonite, pillaring with the same polymer improved catalytic properties. Addition of $\mathrm{Cu}$, increases the $\mathrm{NO}$ conversion in following orders: $7 \%>5 \%>3 \%$ at 250 and $300{ }^{\circ} \mathrm{C}$; $5 \%, 3 \%, 7 \%$ at $350{ }^{\circ} \mathrm{C}$. It is visible especially at $350{ }^{\circ} \mathrm{C}$, where $\mathrm{NO}$ conversion for $\mathrm{Cu}-$ modified samples is highest for VN20g5 (as compared with all polymer-modified ones), which is $94.3 \%$. These results correspond to Chmielarz et al. research [8-9], where NO conversion higher than $80 \%$ was reported. Studies for other layered materials, also show promising results, high levels of NO conversion, at various temperatures (usually $\sim 350{ }^{\circ} \mathrm{C}$ ). This parameter, obtained for PILCs (pillared interlayered clays) modified with copper goes up to almost $100 \%$ at $350{ }^{\circ} \mathrm{C}$ [10]. Polymer-modified sample (VN20g) shows best NO conversion at 250 and $300^{\circ} \mathrm{C}$, however at $350{ }^{\circ} \mathrm{C}$ it is only slightly lower (as well as catalysts with addition of $\mathrm{Cu}$ ) than sample VN20 without further modifications. 
Table 3. SBET of obtained samples

\begin{tabular}{lcccccc}
\hline & \multicolumn{6}{c}{ Sample } \\
\hline $\mathrm{S}_{\text {BET }}$ & $\mathrm{V}$ & $\mathrm{VN20}$ & $\mathrm{VN} 20 \mathrm{~g}$ & $\mathrm{VN} 20 \mathrm{~g} 3$ & $\mathrm{VN} 20 \mathrm{~g} 5$ & VN20g7 \\
\hline $\mathrm{m}^{2} / \mathrm{g}$ & 5 & 6 & 7 & 2 & 3 & 2 \\
\hline
\end{tabular}

Table 3 shows specific surface area $\left(\mathrm{S}_{\mathrm{BET}}\right)$ of obtained samples. Nitrogen physisorption on catalysts was performed using ASAP 2020 Micromeritics instrument after degassing at $105{ }^{\circ} \mathrm{C}$ for $24 \mathrm{~h}$ at $1 \mathrm{~Pa}$ vacuum. The adsorption-desorption isotherms of nitrogen at $-196{ }^{\circ} \mathrm{C}$ were treated by the standard Brunauer-Emmett-Teller (BET) procedure. $\mathrm{S}_{\mathrm{BET}}$ for $p / p_{0}$ range $=0.05-0.25$ was calculated [11]. These results show slight increase in $\mathrm{S}_{\mathrm{BET}}$ of samples modified only via acid activation and pillared with polymer. However, addition of copper seems to decrease specific surface area. This is cause simply by deposition of copper species on the surface, and, what is also possible, partially inside the pores. Hence the lower parameter. Additionaly, as shown in Fig 3, partial subsidence of the structure has occured, which is indicated by amorphous part in XRD diffractogram.

Figure 4, which is an UV-Vis spectra of modified samples, gives information about $\mathrm{Cu}$ modification. According to Chmielarz et al. [9], the absorption band centered at $225 \mathrm{~nm}$, here observed for each $\mathrm{Cu}$-impregnated sample, is attributed to isolated $\mathrm{Cu}^{2+}$ species. Additional absorption band, reported around $360 \mathrm{~nm}$, and attributed to charge-transfer between $\mathrm{Cu}^{2+}$ and oxygen in oligonucelar $[\mathrm{Cu}-\mathrm{O}-\mathrm{Cu}]_{\mathrm{n}}$ species has not been observed, thus indicating that only $\mathrm{Cu}^{2+}$ species exist in prepared samples [9].

According to Chmielarz et al. [8], vermiculites are stable materials in tested temperatures, as compared to activated carbons, which undergo oxidation to $\mathrm{CO}_{2}$ at elevated conditions.

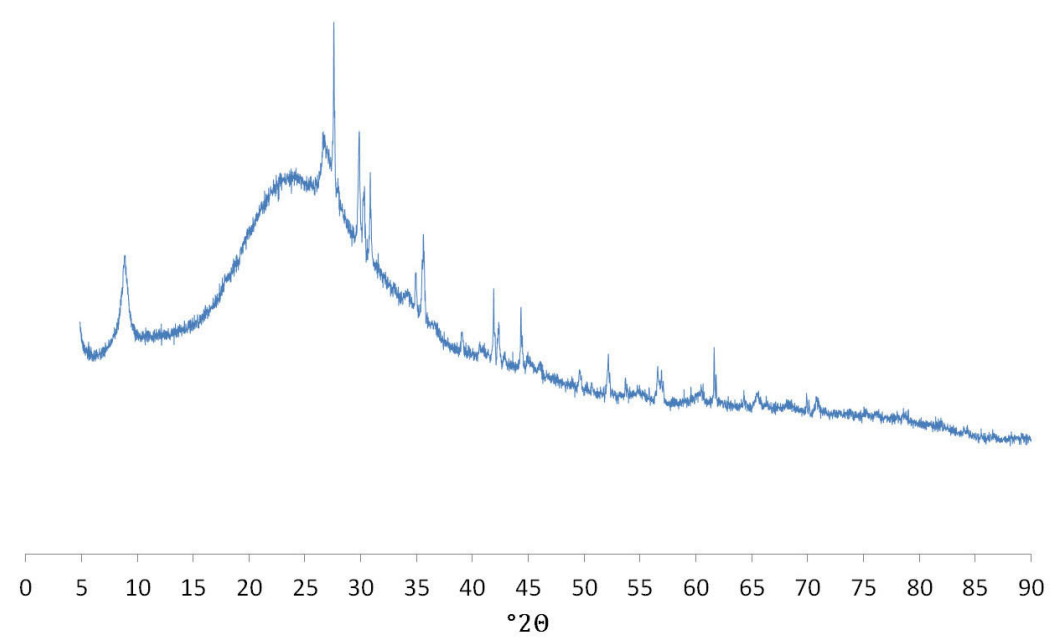

Fig. 3. XRD pattern for acid activated vermiculite (VN20) 


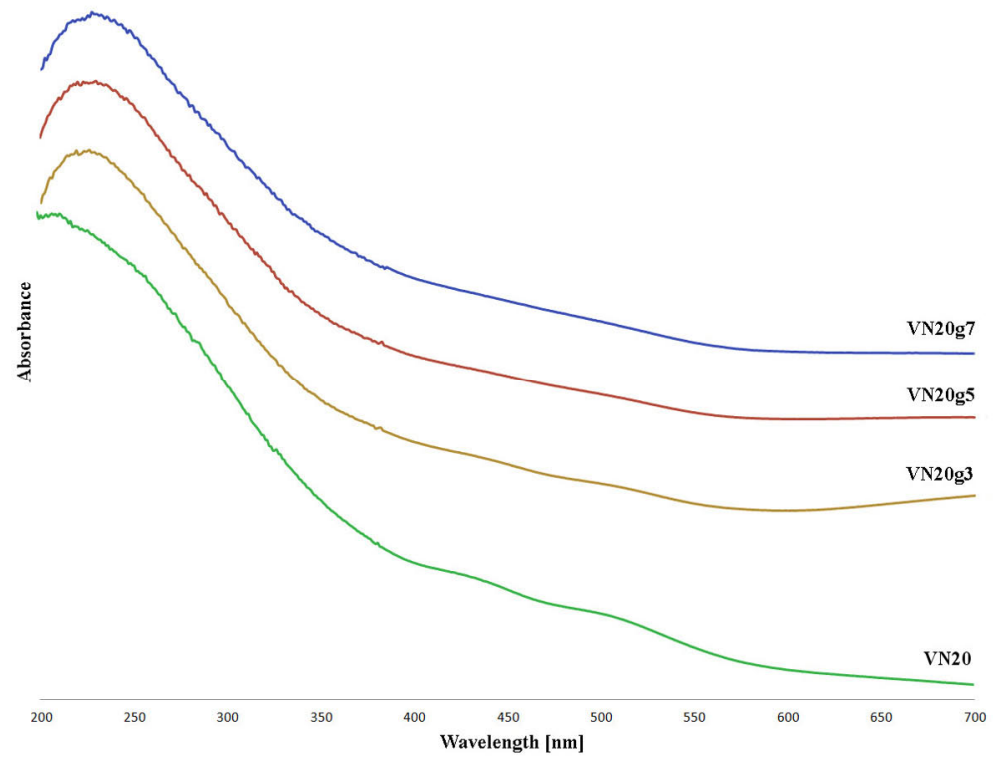

Fig. 4. UV-Vis spectra of base sample VN20 (not modified with $\mathrm{Cu}$ ) and samples VN20g3, VN20g5 and $\mathrm{VN} 20 \mathrm{~g} 7$, impregnated with $\mathrm{Cu}$, respectively 3,5 and $7 \%$ wt.

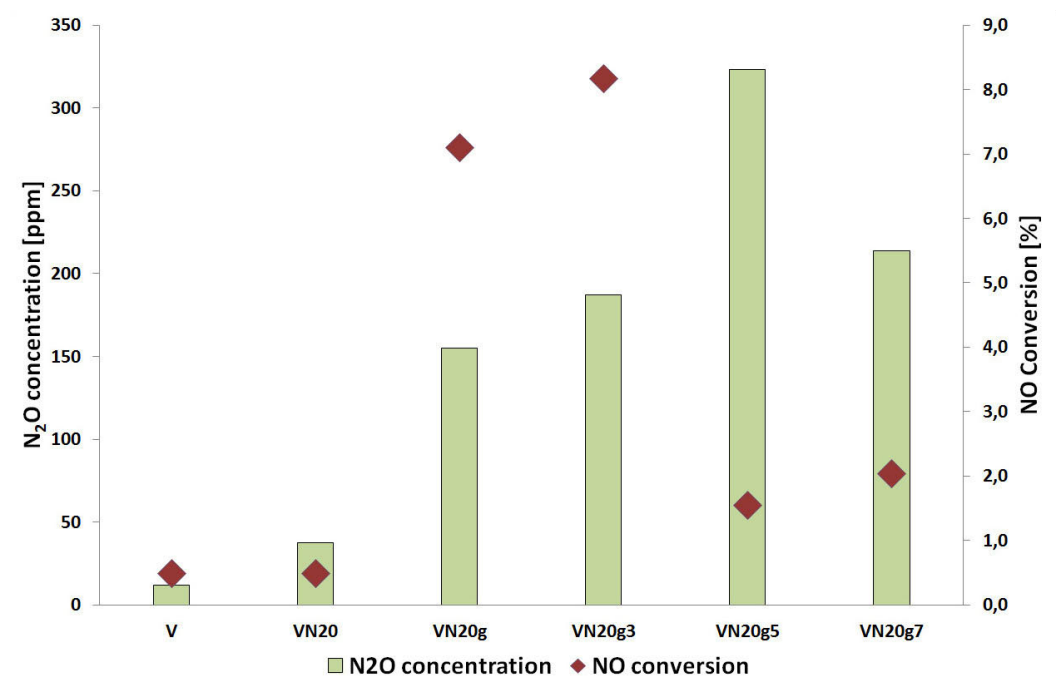

Fig. 5. $\mathrm{N}_{2} \mathrm{O}$ concentration at the outlet and $\mathrm{NO}$ conversion at $150^{\circ} \mathrm{C}$ 


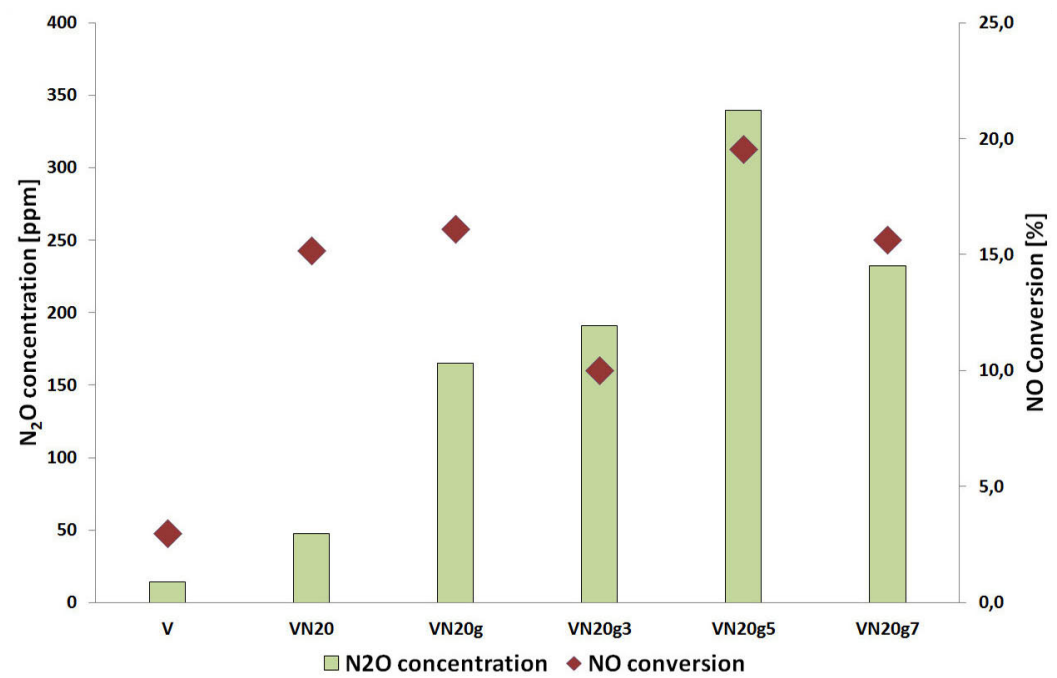

Fig. 6. $\mathrm{N}_{2} \mathrm{O}$ concentration at the outlet and $\mathrm{NO}$ conversion at $200^{\circ} \mathrm{C}$

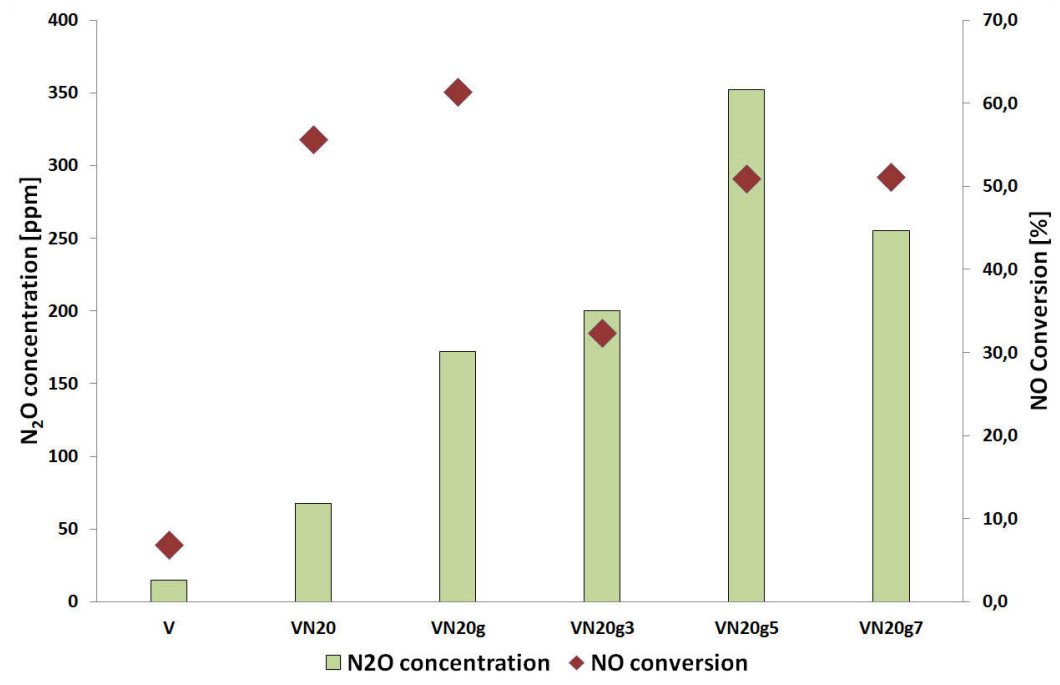

Fig. 7. $\mathrm{N}_{2} \mathrm{O}$ concentration at the outlet and $\mathrm{NO}$ conversion at $250^{\circ} \mathrm{C}$ 


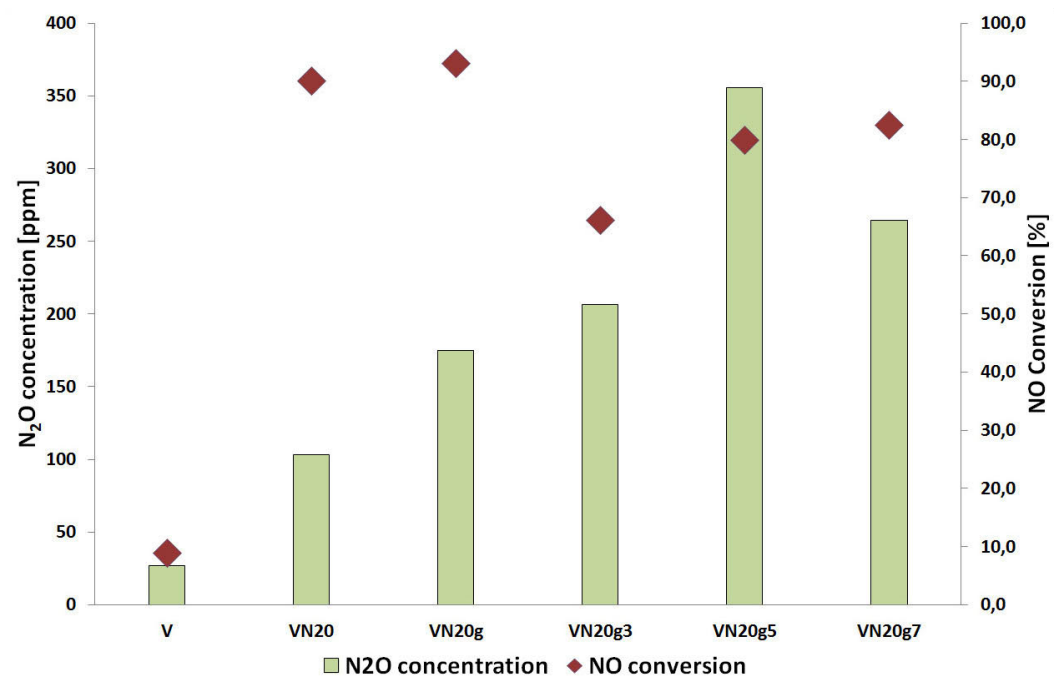

Fig. 8. $\mathrm{N}_{2} \mathrm{O}$ concentration and at the outlet $\mathrm{NO}$ conversion at $300^{\circ} \mathrm{C}$

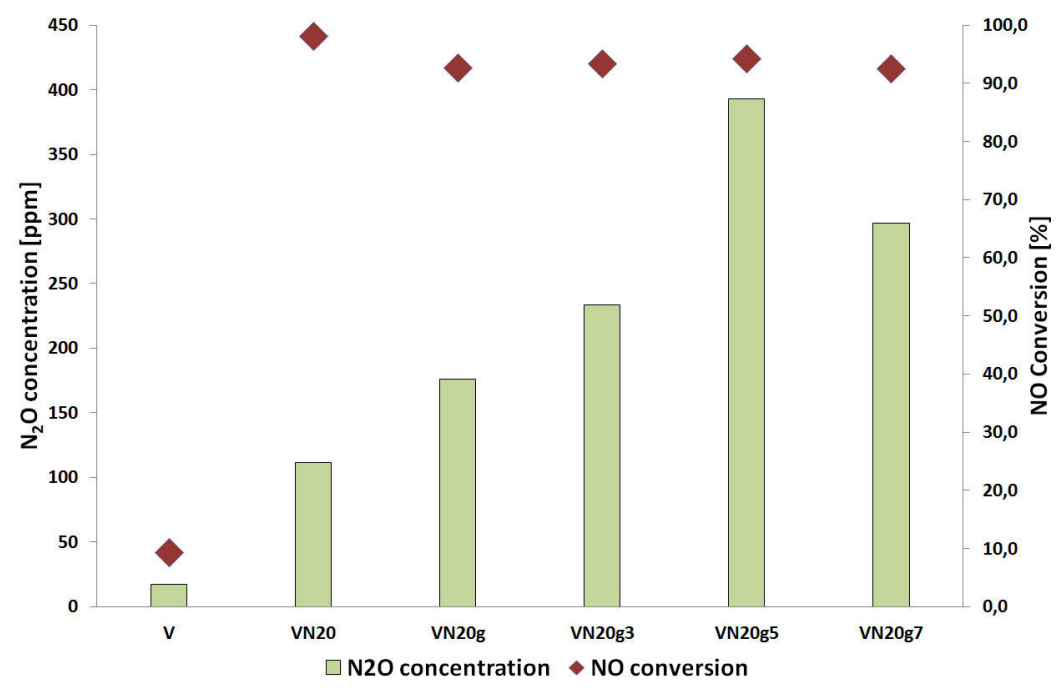

Fig. 9. $\mathrm{N}_{2} \mathrm{O}$ concentration at the outlet and $\mathrm{NO}$ conversion at $350^{\circ} \mathrm{C}$ 


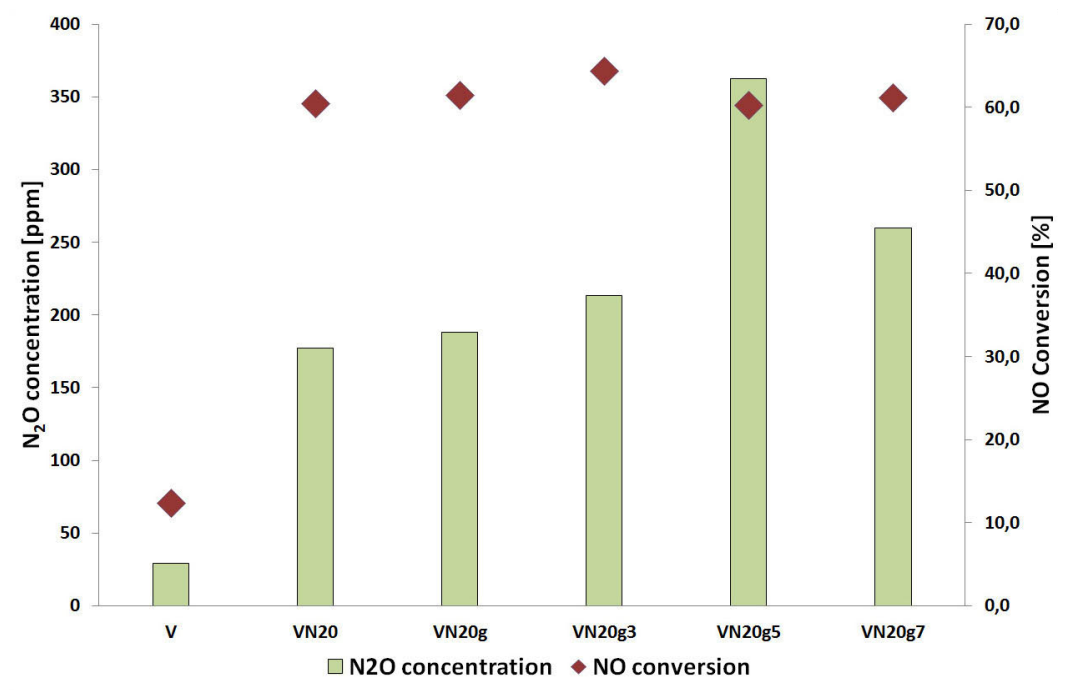

Fig. 10. $\mathrm{N}_{2} \mathrm{O}$ concentration at the outlet and $\mathrm{NO}$ conversion at $400^{\circ} \mathrm{C}$

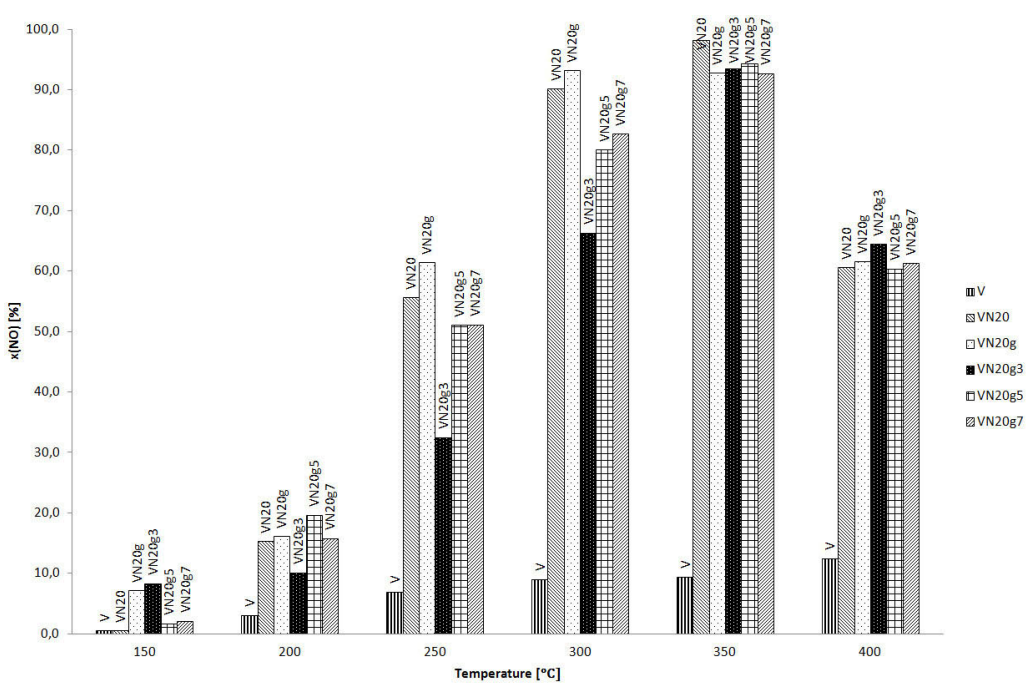

Fig. 11. NO conversion of all samples at temperatures ranging from 150 to $400{ }^{\circ} \mathrm{C}$

\section{Conclusion}

The aim of this work was to study the influence of the copper amount on catalytic properties of modified vermiculites. Raw supplied vermiculite was modified by acid activation with nitric acid, pillaring with $\mathrm{Al}$ oligocations and polymer (polyamide), as well as impregnation with $\mathrm{Cu}$.

Catalytic tests have shown promising results. Polymer, and $\mathrm{Cu}$-modified samples perform well at $350{ }^{\circ} \mathrm{C}$; $\mathrm{NO}$ conversions are the highest among all temperatures $(94.3 \%$ for $\mathrm{VN} 20 \mathrm{~g} 5$, 
92.6\% for VN20g7). Modification with $\mathrm{Cu}$ slightly improves catalytic performance of polymer-modified vermiculites at this temperature.

Due to partial subsidence of the structure, the dependence of $\mathrm{Cu}$-modification with other modification cannot be clearly described. Cu species decreased specific surface area, because of their deposition on the surface. Pillaring itself increases $\mathrm{S}_{\mathrm{BET}}$, however it may also allow the penetration of pores with active material.

The work was supported by AGH 11.11.210.213.

\section{References}

1. B. Samojeden, Paliwa i energia XXI wieku, Wpływ modyfikacji węgli aktywnych zwiąkami azotu na ich wtaściwości fizykochemiczne, 519 - 536, (2014)

2. B. Samojeden, J. Klinik, T. Grzybek, H. Papp, Charakterystyka modyfikowanych węgli aktywnych jako katalizatorów w reakcji DeNOx, Gospodarka Surowcami Mineralnymi 24, 295 - 303, 2008

3. B. Samojeden, Paliwa i energia XXI wieku, Wegle aktywne $w$ procesach usuwania tlenków azotu z gazów odlotowych ze źródet stacjonarnych, 426 - 431, (2014)

4. L. Chmielarz, A. Kowalczyk, M. Michalik, B. Dudek, Z. Piwowarska, A. Matusiewicz, App. Clay Sci. 49, 156 - 162, 2010

5. G. Lagaly, K. Beneke, Colloid Polym Sci 269, 1198 - 1211, 1991

6. B. Samojeden, T. Grzybek, Energy 116, 1484 - 1491, 2016

7. M. Motak, Cat. Today 137, 247-252, 2008

8. L. Chmielarz, P. Kuśtrowski, M. Michalik, B. Dudek, Z. Piwowarska, R. Dziembaj, Cat. Today 137, $242-246,2008$

9. L. Chmielarz, P. Kuśtrowski, Z. Piwowarska, B. Dudek, B. Gil, M. Michalik, App. Cat. B: Environmental 88, 331 - 340, 2009

10. L. Chmielarz, Z. Piwowarska, P. Kuśtrowski, B. Gil, A. Adamski, B. Dudek, M. Michalik, App Cat B: Environmental 91, 449 - 459, 2009

11. Brunauer S, Emmett PH, Teller E, J Am Chem Soc 60, 309-319, 1938 